\title{
Development, characterisation and diagnostic application of monoclonal antibodies against Yersinia pestis fibrinolysin and coagulase
}

\author{
V. A. FEODOROVA and Z. L. DEVDARIANI
}

Laboratory of Hybridomas, Russia State Antiplague Research Institute 'Microbe', Saratov, Russia

\begin{abstract}
A library of monoclonal antibodies (MAbs) which recognised different epitopes of Yersinia pestis fibrinolysin (Fib) was developed. These MAbs were species-specific and demonstrated no cross-reaction in indirect immunofluorescence tests (IIFT) with other gram-negative bacteria possessing plasminogen activator activity. All the MAbs provided equally high levels of immunofluorescence with $\mathrm{pPst}^{+} \mathrm{Y}$. pestis strains cultivated at $37^{\circ} \mathrm{C}$ and at $28^{\circ} \mathrm{C}$. In all cases, the MAbs inhibited both fibrinolytic and coagulase (Coag) activities of $Y$. pestis in Fib-activity inhibition and coagulase-activity inhibition reactions, and reacted with 35- and 37-kDa proteins of $Y$. pestis in immunoblotting, demonstrating bifunctional activity possibly similar to the properties of MAbs produced by hybrid hybridomas. On the basis of these and earlier studies, the immunochemical identity of Fib and Coag, two distinct subunits of a bifunctional fusion protein whose specific functional activity depends upon the temperature factor, was established. A new rapid, cheap, strictly specific and safe dot-ELISA based on the use of MAb against $Y$. pestis Fib (MAb-Fib) for reliable identification of $Y$. pestis strains was developed. This technique has great advantages over monoclonal diagnostic kits based on the use of $M A b$ against $Y$. pestis fraction I (FI) because it allows detection of plague bacilli grown at $37^{\circ} \mathrm{C}$ as well as at $28^{\circ} \mathrm{C}$. This dot-ELISA will be valuable as a clinical diagnostic tool and might be applicable to field studies and plague surveillance.
\end{abstract}

\section{Introduction}

Yersinia pestis possesses fibrinolytic (plasminogen activator) and coagulase activities that play a significant role in the pathogenesis of plague [1-3]. These activities are encoded by the same gene, pla, which has been cloned and sequenced and is present in a 9.5-kb plasmid designated pPst, or pPCP1 $[2,4-7]$. The modulation between coagulase and fibrinolytic activities is temperature-dependent. Fibrinolytic activity is most evident at temperatures above $30^{\circ} \mathrm{C}$, but coagulase activity increases with lower temperatures $\left(<30^{\circ} \mathrm{C}\right)$ of $Y$. pestis incubation $[2,5,6]$. These activities are determined by two products of pla gene - peptides of 37 and $35 \mathrm{kDa}[4-6]$ - but it is still unclear how the biochemical activities are distributed between the proteins.

Received 18 Feb 1999; revised version accepted 28 July 1999.

Corresponding author: Dr V. A. Feodorova (e-mail: postmaster@microbe.saratov.su).
A Ithough pla-related genes of several other pathogenic bacteria are chromosomal, in contrast to the location of pla on a plasmid in Y. pestis, their respective genes exhibit a striking degree of homology with that of the plague agent [7] and it is not clear if the pla-encoded products of $Y$. pestis differ from those of other bacteria in functional activity and antigenic specificity. The difficulties of purification [8] have led to loss of fibrinolysin (Fib) enzyme activity or to preparations contaminated with carbohydrate, which limits characterisation with homologous antisera.

In this study, several monoclonal antibodies (MAbs) specific for different epitopes of the Fib molecule were characterised. A special system of screening of MAbs based on different properties of the antigen was used to examine the MAbs activity against both peptides encoded by the pla gene. One of the MAbs was used to develop a new rapid, strictly specific, sensitive and safe dot-ELISA and the properties of this MAb (-Fib) were compared with those of $M A b$ against fraction I, $\mathrm{FI}(\mathrm{MAb}-\mathrm{FI})$ for the recognition of $\mathrm{Y}$. pestis strains cultivated at $28^{\circ} \mathrm{C}$ as well as at $37^{\circ} \mathrm{C}$. The possibility of 
its further application to systems for monitoring plague infection in natural foci is discussed.

\section{$M$ aterials and methods}

\section{Bacterial strains}

The strains examined included $110 \mathrm{Y}$. pestis isolates from natural plague foci of the Community of Independent States (CIS), M ongolia, China, Vietnam, Pakistan, India, A frica and South A merica; 15 Y. pestis strains constructed by genetic modification and harbouring different combinations of their innate plasmids including isogenic variants of $Y$. pestis EV (Y. pestis EV) $\left(\mathrm{pPst}^{+} ; \mathrm{pCad}^{+} ; \mathrm{pFra}^{+}\right), \mathrm{Y}$. pestis KM-216 $\left(\mathrm{pPst}^{+}\right.$; $\left.\mathrm{pCad}^{-} ; \mathrm{pFra}^{-}\right)$, Y. pestis $\mathrm{KM}-218$ (pPst $^{-} ; \mathrm{pCad}^{-}$; $\mathrm{pFra}^{-}$) [9]; $65 \mathrm{Y}$. pseudotuberculosis strains (serovars I-VI); 12 Y. enterocolitica strains; 10 Escherichia coli strains; 10 Salmonella strains; eight Shigella strains and five Proteus strains. The $Y$. pestis strains were cultured on Hottinger agar (pH 7.2-7.4) incubated at $28^{\circ} \mathrm{C}$ for $48 \mathrm{~h}$. For some experiments, several Y. pestis strains were grown at $28^{\circ} \mathrm{C}$ for $24 \mathrm{~h}$ and then incubated at $37^{\circ} \mathrm{C}$ for $24 \mathrm{~h}$. The remaining bacteria were grown on Hottinger agar (pH $7.2-7.4)$ at $37^{\circ} \mathrm{C}$ for $48 \mathrm{~h}$. $\mathrm{Y}$. pestis strain 231 cultivated on Hottinger agar $(\mathrm{pH} 7.2-$ 7.4 ) at $28^{\circ} \mathrm{C}$ for $24 \mathrm{~h}$ was used for acute challenge of mice.

\section{Antigens}

Fib was extracted from E. coli strain K802(pEK 4) which had been transformed by insertion of the unique Y. pestis pla gene, and purified as described previously $[6,8]$. Chemical analysis showed that, in addition to proteins, the preparation contained $(13.0 \pm 3.0) \%$ of carbohydrate and $(6.0 \pm 1.5) \%$ of lipids.

Lipopolysaccharides (LPS) from $Y$. pestis EV, Y. pseudotuberculosis serovar I strains and $E$. coli strain K 802 were purified by the Westphal [10] or the Galanos [11] procedures. LPS from E. coli 0111:B 4 (Sigma) was also used. Pure lipid A from Y. pestis EV, E. coli K802 and E. coli 0111:B4 were produced according to Galanos [12].

\section{Preparation of hybridomas producing MAbs}

Female BALB/c mice, 6-10 weeks old and weighing 18-20 g, were given three intraperitoneal doses of $\mathrm{Fib}$ at 2-week intervals, the first injection comprised $25 \mu \mathrm{g}$ of Fib emulsified in complete Freund's adjuvant (Sigma) and the remaining injections comprised $50 \mu \mathrm{g}$ of the antigen. The sensitised spleen cells were fused with a mouse myeloma cell line Sp2/0-Ag 14 according to the method of Galfre et al. [13]. The hybridoma cells obtained were cloned by limiting dilution. MAbs produced by hybridomas were screened by an indirect immunofluorescence test (IIFT), ELISA and reaction of Fib-activity inhibition (RFAI).
MAbs

MAb-FI, produced by hybridoma Y p.FI.B B $_{2} \mathrm{D}_{3} . \mathrm{Sp}$ [14] and $M A b-F i b(M A b-A)$ were obtained from the ascitic fluids of $B A L B / C$ mice inoculated intraperitoneally with hybridoma cells and purified by affinity chromatography as described previously [15].

\section{Determination of MAbs class and subclass}

The class and subclass of all MA bs were determined by immunodiffusion by the method of Ouchterlony with agarose (Difco) $1 \%$ in $10 \mathrm{~mm}$ PBS (pH 7.2-7.4) and lyophilised antisera to mouse immunoglobulin $M$ (IgM), IgG, IgG $1, \operatorname{IgG}_{2 a}, \operatorname{IgG}_{2 b}$ and $\operatorname{IgG}_{3}$ (Sigma) [16].

\section{IIFT}

The following bacterial strains were used for the IIFT: (i) for initial screening, Y. pestis EV; (ii) after cloning, three $Y$. pestis strains with different plasmid profiles Y. pestis EV, KM-216, KM-218; (iii) for studying specific properties, 139 different strains of closely related bacteria. Slide smears were prepared from a suspension of live bacteria containing $10^{7}-10^{8}$ cells $/ \mathrm{ml}$. All the smears were air-dried and fixed with ethyl alcohol $96 \%$ and incubated with cultural fluids of tested hybridomas of MAbs. The smears were stained with FITC-labelled rabbit anti-mouse immunoglobulins for $20 \mathrm{~min}$, washed in phosphate-buffered saline (PBS; pH 7.2) and air-dried. Then, $0.05 \mathrm{ml}$ of glycerol in PBS was placed on each smear and covered with a coverslip. The intensity of immunofluorescence was estimated visually with a luminescent microscope ML-2 (Lomo, Russia). RPMI-1640 medium (Flow Laboratories) and culture supernate of myeloma cells maintained in RPMI-1640 medium were used as negative controls.

IIFT was also used for comparison of specificity of $M A b-F I$ and MAb-Fib by the procedure described above. A scitic fluids of intact BALB / c mice inoculated intraperitoneally with $1.5 \times 10^{6} \mathrm{Sp} 2 / 0-\mathrm{Ag} 14$ myeloma cells were used as a negative control.

\section{ELISA}

At different stages of the investigation several modifications of ELISA were used. At the initial screening, $M A b$ production was measured by ELISA performed in 96-well microtitration plates (VNIIM edpolymer, Russia). Briefly, $100 \mu \mathrm{l}$ of cell culture supernate were added to wells previously coated with purified Fib at $10 \mu \mathrm{g}$ of $\operatorname{protein} / \mathrm{ml}$ in PBS. Then, $100 \mu \mathrm{l}$ of horseradish peroxidase-labelled rabbit anti-mouse immunoglobulins (Sigma) were added to each well. As substrate, $100 \mu \mathrm{l}$ of 2,2'-azinobis(3-ethylbenzthiazoline sulphonic acid) $22.3 \mathrm{mg} / \mathrm{ml}$ in $0.05 \mathrm{~mm}$ citrate buffer (pH 4.0) with $\mathrm{H}_{2} \mathrm{O}_{2} \quad 0.0003 \%$ was used. The $\mathrm{OD}_{405}$ was measured in a Titertec Multiscan spectrophotometer 
(Flow Laboratories). An OD value of 0.2 above background was considered a positive result. RPMI1640 medium was used as a negative control.

Indirect ELISA was also used for studying the ability of MAbs to cross-react with various bacterial LPS and lipid $A$. The plates were sensitised with $100 \mu \mathrm{l} /$ well of the antigen samples in PBS at a concentration of $10 \mu \mathrm{g} / \mathrm{ml}$. Then, $100 \mu \mathrm{l}$ of culture fluid containing MAbs was added to each well. Peroxidase-labelled anti-mouse IgG was employed as conjugate.

Indirect dot-ELISA. The MAbs were tested for their substrate specificity, i.e., their ability to react with protein or carbohydrate fractions of Fib preparations in native and protein-free samples of the antigen as recommended by $M$ agnani [17]. For protein digestion, the preparation was treated with proteinase $\mathrm{K}$ (PK) (Calbiochem) according to Hitchcock and Brown [18]. Several drops of each sample (native and PK-digested) were placed on to a nitrocellulose membrane (NCM) pore size $22 \mu \mathrm{m}$ (Schleicher-Schuell) and fixed with ethyl alcohol $96 \%$ for $20 \mathrm{~min}$. A fter being washed three times in PBS and blocked with skimmed milk 3\% for $15 \mathrm{~min}$, the NCM was incubated for $15 \mathrm{~min}$ with the appropriate MAbs. Peroxidase-labelled anti-mouse IgG were employed as a conjugate. O-Dianisidine (Sigma) was used as a substrate. Finally, the NCM was dried and observed for colour differentiation.

Direct dot-ELISA. This was used to compare specific activity of MAb-Fib and MAb-FI and to detect plague bacilli in suspensions of organs of infected mice. B riefly, bacterial suspensions were prepared with doubling dilutions (from an initial dilution of $1 \times 10^{12}$ to a final dilution of $1 \times 10$ microbial cells/ml) in PBS. A drop (c. $2 \mu \mathrm{l}$ ) of each dilution was placed on to a NCM and fixed with ethyl alcohol $96 \%$ for $20 \mathrm{~min}$. After being washed three times in PBS and blocked with skimmed milk $3 \%$ for $15 \mathrm{~min}$, the NCM was incubated for $15 \mathrm{~min}$ with the relevant MAbs, peroxidase-labelled according to $\mathrm{Nakane}$ and Kawaoi [19]. 0-Dianisidine (Sigma) was used as a substrate. The dried NCM was observed for colour differentiation.

Suspensions of organs were dotted on to the NCM at one single dilution. Dot-ELISA was performed as above. Bovine serum albumin (BSA; Sigma) $1 \%$ in PBS was used as a negative control in both cases.

\section{Specimens of murine organs for dot-ELISA}

Twenty BALB/C mice (8-12 weeks old, male and female) were infected subcutaneously with $1 \times 10^{2}$ microbial cells of virulent $Y$. pestis strain 231 suspended in $0.2 \mathrm{ml}$ of $0.15 \mathrm{M} \mathrm{NaCl}$. The deaths associated with $Y$. pestis inoculation were observed not later than the 6th day after challenge. Regional lymph nodes, liver and spleen were recovered and a suspension of each organ in $0.15 \mathrm{M} \mathrm{NaCl}$ was prepared as described by Naumov and Samoilova [20].

\section{RFAI}

Plates containing human fibrinogen were prepared as described by Beesley et al. [3]; $10 \mu \mathrm{l}$ of hybridoma cell culture supernate with $5 \mu \mathrm{l}$ of live $\mathrm{Y}$. pestis KM-216 $\left(\mathrm{pPst}^{+}\right)$suspension $\left(10^{8}-10^{9} \mathrm{cells} / \mathrm{ml}\right.$ in $0.15 \mathrm{M} \mathrm{NaCl}$ solution) were added to the wells of the plates and incubated for $18 \mathrm{~h}$ at $37^{\circ} \mathrm{C}$. The ability of MAbs to inhibit fibrinolysis was estimated by the absence of a zone of lysis around wells. Y. pestis KM-216 $\left(\mathrm{pPst}^{+}\right)$ cells plus equine antiplague antiserum containing antiFib antibodies at dilutions of 1 in 1 to 1 in 128, were used as a positive control (absence of a zone of lysis). Y. pestis KM-216 $\left(\mathrm{pPst}^{+}\right.$) (which has fibrinolytic activity) was used as a negative control (presence of a zone of lysis).

\section{Reaction of Coag-activity inhibition (RCAI)}

The micromethod described by Naumov and Samoilova [20] was performed to determine the ability of MAbs to inhibit coagulase activity. B riefly, $10 \mu \mathrm{l}$ of MAbs with $5 \mu \mathrm{l}$ of live $\mathrm{Y}$. pestis $\mathrm{KM}-216\left(\mathrm{pPst}^{+}\right)$suspension $\left(10^{8}-10^{9} \mathrm{cell} / \mathrm{s} / \mathrm{ml}\right.$ in $0.15 \mathrm{M} \mathrm{NaCl}$ solution) were added to $100 \mu \mathrm{l}$ of rabbit plasma containing sodium citrate $1 \%$ and incubated for $2-3 \mathrm{~h}$ at $28^{\circ} \mathrm{C}$. The reaction was estimated by the formation of a clot. Y. pestis K M -216 (which has coagulase activity) was used as a positive control (presence of a clot). Equine antiplague antiserum containing anti-Coag antibodies, Y. pseudotuberculosis strain 66 or pure rabbit plasma were used as negative controls (absence of a clot).

\section{SDS-PAGE}

Fib and whole-cell lysates of $Y$. pestis EV and $Y$. pseudotuberculosis, both cultivated at $28^{\circ} \mathrm{C}$ or $37^{\circ} \mathrm{C}$, were subjected to SDS-PAGE according to Laemmli [21], with a $4 \%$ stacking gel and $12.5 \%$ separating gel Electrophoresis was at $35 \mathrm{~mA}$ constant current in Trisglycine ( $\mathrm{pH}$ 8.3) plus SDS $0.1 \%$ buffer for c. 2.5 h. A set of low-mol. wt markers (Sigma) was used. Gels were counterstained with Coomassie Brilliant Blue $R$ 250 (Sigma) $0.2 \% \mathrm{w} / \mathrm{v}$ in ethanol $25 \% \mathrm{v} / \mathrm{v}$, acetic acid $7 \% \mathrm{v} / \mathrm{v}$.

\section{Immunoblotting}

The method of Towbin et al. [22] was used. Protein bands in the polyacrylamide gel were blotted electrophoretically on to a NCM, pore size $22 \mu \mathrm{m}$ (Schleicher-Schuell), for $1 \mathrm{~h}$ at $25^{\circ} \mathrm{C}$. A fter being blocked with skimmed milk $3 \%$ in PBS and washed, the membrane was incubated with the MAbs for $12 \mathrm{~h}$ at $4^{\circ} \mathrm{C}$. Protein bands were visualised with peroxidase-conjugated rabbit anti-mouse IgG (Sigma). 0-Dianisidine (Sigma) was used as a substrate. 


\section{Results}

\section{Selection and testing of MAbs}

In all, $3 \%$ of the MAbs reacted with $Y$. pestis $E V$ cells in IIFT whereas $23 \%$ of the MAbs were positive in ELISA with the Fib antigen itself. The same $26 \%$ of MAbs inhibited fibrinolytic activity of $Y$. pestis when tested in RFAI.

A fter cloning, 36 clones of hybridomas were selected by IIFT with whole cells of Y. pestis with different plasmid profiles. Of the hybridomas, 27 produced $M A b s$ that were positive in RFAI. The remaining nine hybridomas produced RFAI-negative MAbs. All the $M A b s$ were divided into five groups $(A-E)$ according to their specific activity (Table 1 ). Within each group, MAbs reacted with the same epitope and this was confirmed by an epitope analysis (data not shown). Thus, MA bs directed against five different epitopes of the Fib-antigen were obtained. A single $M A b$ from each of the five groups was chosen and designated $M A b-A, M A b-B, M A b-C, M A b-D$ and $M A b-E$, respectively. All the $M A b s$ were of the immunoglobulin $\mathrm{G}_{1}$ subclass.

When tested in dot-ELISA with native and PK-digested Fib, MA bs A - D appeared to react with only the native preparation. No reaction with PK -digested antigen was observed. MAb-E reacted with both native and PKdigested Fib.

In indirect ELISA with various LPS and lipid $A$ preparations, only $M A b-E$ reacted with $Y$. pestis LPS whereas other MAbs demonstrated no cross-reaction with the above-mentioned antigens.

\section{Specificity of MAbs}

In IIFT, MAb-A detected all pPst ${ }^{+}$strains of $Y$. pestis independently of the presence of other plasmids. MAb$B$ and $M A b-C$ were shown to give fewer $(p<0.05)$ positive reactions with $Y$. pestis harbouring pPst. No positive reactions with $Y$. pestis lacking pPst and other gram-negative bacteria were observed. MAD-D gave a negative reaction with all the strains used. The temperature of cultivation did not influence the results of IIFT. MAb-E reacted with all Y. pestis strains, including those lacking pPst, and with Y. pseudotuberculosis strains (Table 2).

\section{Effect of MAbs on coagulase activity}

All 27 MAbs that were positive in RFAI (groups A-D) inhibited the coagulase activity of $Y$. pestis but nine RFAI-negative strains did not.

\section{Band patterns revealed by MAbs on} immunoblotting

Whole-cell lysates of $Y$. pestis EV and $Y$. pseudotuberculosis cultivated at $28^{\circ} \mathrm{C}$ and $37^{\circ} \mathrm{C}$ and $\mathrm{Fib}$ preparation were separated from the gel on to nitrocellulose and incubated with MAb-A. As shown in Fig. 1, MAb-A gave strong positive immunoblotting with two peptides of mol.wts 35 and $37 \mathrm{kDa}$ in the fractionated $\mathrm{Fib}$ and $\mathrm{Y}$. pestis $\mathrm{EV}$, independently of the temperature of cultivation. B oth bands were of the same intensity. There was no cross-reaction with $Y$. pseudotuberculosis. Immunoblotting with MAb-B and $\mathrm{MAb}-\mathrm{C}$ gave the same results.

Detection of $Y$. pestis by MAb-FI and MAb-Fib (MAb-A)

Two MAbs - MAb-FI, obtained and characterised in our laboratory previously [14] and M Ab-Fib (MAb-A) - were tested in IIFT. B oth MAbs gave positive results at similar working (optimal) dilutions (1 in 2500) and were species-specific, i.e., recognised only $Y$. pestis strains and not other gram-negative bacteria used in the current investigation. However, some differences in the reaction of MAbs with $Y$. pestis strains cultivated at $28^{\circ} \mathrm{C}$ and $37^{\circ} \mathrm{C}$ were observed (Table 3). MAb-FI demonstrated a positive reaction only with $Y$. pestis strains cultivated at $37^{\circ} \mathrm{C}$, whereas $\mathrm{MAb}$-Fib reacted with $Y$. pestis strains independently of the cultivation temperature. Similar results were obtained in the dotELISA. Both MAbs detected $Y$. pestis strains at a concentration of $10^{3}-10^{5}$ microbial cells $/ \mathrm{ml}$. In suspensions of organs of plague-infected mice $Y$. pestis strain 231 was detected in dot-ELISA by both MAb$\mathrm{Fib}$ and MAb-FI.

Table 1. Specific activity of RFAI-positive MAbs produced by recloned hybridomas in IIFT

\begin{tabular}{|c|c|c|c|c|c|}
\hline \multirow{3}{*}{$\begin{array}{l}\text { Groups of } \\
\text { hybridomas }\end{array}$} & \multirow{3}{*}{$\begin{array}{l}\text { Number of } \\
\text { hybridomas/ } \\
\text { group }\end{array}$} & \multicolumn{3}{|c|}{ Strains of $Y$. pestis and plasmid profiles } & \multirow{3}{*}{$\begin{array}{c}\text { Percentage of } \\
\text { positive } \\
\text { reactions }\end{array}$} \\
\hline & & EV & KM -216 & K M - 218 & \\
\hline & & $\left(\mathrm{pPst}^{+} ; \mathrm{pCad}^{+} ; \mathrm{pFra}^{+}\right)$ & $\left(\mathrm{pPst}^{+} ; \mathrm{pCad}^{-} ; \mathrm{pFra}{ }^{-}\right)$ & $\left(\right.$pPst $\left.^{-} ; \mathrm{pCad}^{-} ; \mathrm{pFra}^{-}\right)$ & \\
\hline $\bar{A}$ & 15 & + & + & - & 55.5 \\
\hline B & 8 & - & + & - & 29.6 \\
\hline C & 2 & + & - & - & 7.4 \\
\hline D & 3 & - & - & - & 11.1 \\
\hline
\end{tabular}


Table 2. Comparative characteristics of specificity of different MAb groups

\begin{tabular}{|c|c|c|c|c|c|c|c|}
\hline \multirow{2}{*}{$\begin{array}{l}\text { Bacterial species and } \\
\text { plasmid profile }\end{array}$} & \multirow{2}{*}{$\begin{array}{l}\text { Number } \\
\text { of strains }\end{array}$} & \multirow{2}{*}{$\begin{array}{c}\text { Cultivation } \\
\text { temperature }\left({ }^{\circ} \mathrm{C}\right)\end{array}$} & \multicolumn{5}{|c|}{ Percentage of positive reactions with $\mathrm{MAb}$ groups } \\
\hline & & & A & B & $C$ & $\mathrm{D}$ & $\mathrm{E}$ \\
\hline \multicolumn{8}{|l|}{ Y. pestis } \\
\hline \multirow[t]{2}{*}{$\mathrm{pPst}^{+} ; \mathrm{pCad}^{+} ; \mathrm{pFra}^{+}$} & 44 & 28 & 100 & 84 & 100 & 0 & 100 \\
\hline & & 37 & 100 & 84 & 100 & 0 & 100 \\
\hline \multirow[t]{2}{*}{$\mathrm{pPst}^{+} ; \mathrm{pCad}^{+} ; \mathrm{pFra}^{-}$} & 8 & 28 & 100 & 75 & 100 & 0 & 100 \\
\hline & & 37 & 100 & 75 & 100 & 0 & 100 \\
\hline \multirow[t]{2}{*}{$\mathrm{pPst}^{+} ; \mathrm{pCad}^{-} ; \mathrm{pFra}^{-}$} & 3 & 28 & 100 & 100 & 33.3 & 0 & 100 \\
\hline & & 37 & 100 & 100 & 33.3 & 0 & 100 \\
\hline \multirow[t]{2}{*}{$\mathrm{pPst}^{+} ; \mathrm{pCad}^{-} ; \mathrm{pFra}^{+}$} & 4 & 28 & 100 & 50 & 75 & 0 & 100 \\
\hline & & 37 & 100 & 50 & 75 & 0 & 100 \\
\hline \multirow{2}{*}{$\mathrm{pPst}^{-} ; \mathrm{pCad}^{+} ; \mathrm{pFra}^{+}$} & 19 & 28 & 0 & 0 & 0 & 0 & 100 \\
\hline & & 37 & 0 & 0 & 0 & 0 & 100 \\
\hline \multirow[t]{2}{*}{$\mathrm{pPst}^{-} ; \mathrm{pCad}^{+} ; \mathrm{pFra}^{-}$} & 2 & 28 & 0 & 0 & 0 & 0 & 100 \\
\hline & & 37 & 0 & 0 & 0 & 0 & 100 \\
\hline \multirow[t]{2}{*}{ pPst $^{-} ; \mathrm{pCad}^{-} ; \mathrm{pFra}^{+}$} & 6 & 28 & 0 & 0 & 0 & 0 & 100 \\
\hline & & 37 & 0 & 0 & 0 & 0 & 100 \\
\hline \multirow[t]{2}{*}{ pPst $^{-} ; \mathrm{pCad}^{-} ; \mathrm{pFra}^{-}$} & 6 & 28 & 0 & 0 & 0 & 0 & 100 \\
\hline & & 37 & 0 & 0 & 0 & 0 & 100 \\
\hline \multirow{2}{*}{ Y. pseudotuberculosis } & 28 & 28 & 0 & 0 & 0 & 0 & 0 \\
\hline & & 37 & 0 & 0 & 0 & 0 & 0 \\
\hline \multirow[t]{2}{*}{ Y. enterocolitica } & 6 & 28 & 0 & 0 & 0 & 0 & 0 \\
\hline & & 37 & 0 & 0 & 0 & 0 & 0 \\
\hline \multirow{2}{*}{ Other micro-organisms* } & 13 & 28 & 0 & 0 & 0 & 0 & 0 \\
\hline & & 37 & 0 & 0 & 0 & 0 & 0 \\
\hline
\end{tabular}

*See Materials and methods.

$\mathrm{kDa}$

$69-$

$46-$

$43-$

$30-$

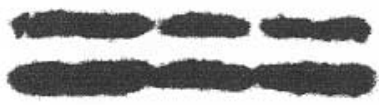

A B

C

\section{D}

E

Fig. 1. Immunoblotting of Fib preparation and whole-cell Iysates of $Y$. pestis and $Y$. pseudotuberculosis with $M A b$ A. Lane A, Fib preparation; B, Y. pestis EV cultivated at $28^{\circ} \mathrm{C} ; \mathrm{C}, \mathrm{Y}$. pestis $\mathrm{EV}$ cultivated at $37^{\circ} \mathrm{C} ; \mathrm{D}, \mathrm{Y}$. pseudotuberculosis strain 66 cultivated at $28^{\circ} \mathrm{C} ; \mathrm{E}, \mathrm{Y}$. pseudotuberculosis strain 66 cultivated at $37^{\circ} \mathrm{C}$. Numbers on the right indicate molecular ratios $\left(\times 10^{3}\right)$ of the standard proteins employed.

\section{Discussion}

The contribution of plasminogen activators to bacterial virulence is well established $[1-3,5,6]$. Although the striking degree of homology between the known plasminogen activators [7] supposes the same mechanism of fibrinolysis [3], Y. pestis Fib contributes to the extreme virulence of the plague agent and to the highly invasive, fulminant character of plague infection [1-3, 6]. In contrast to most gram-negative bacteria whose pla genes are chromsomal, the $Y$. pestis pla gene is located on a unique plasmid - pPst [3-6]. This gene has been cloned, sequenced and shown to have incomplete homology with other plasminogen activators $[4,7]$, but the peculiarities of functional activity and antigenic specificity of its product, $\mathrm{Fib}$, remain unclear. B eing an outer-membrane protein (OM P) $[4,6$, 8], Fib is closely bound to other OMPs and LPS [8]. Attempts at purification of the protein by different methods met with limited success [8] and produced highly hydrophobic preparations containing carbohydrate. The use of such a preparation for immunisation induces anti-LPS antibodies which predominate over antibody to protein antigen. The presence of LPS epitopes in the $Y$. pestis Fib preparation causes extensive cross-reactions with closely related bacteria [8]. At the same time, Fib lacking LPS loses its enzymic activity [8] which indicates significant alteration of native structures of the antigen. With hybridoma technology, it is possible to obtain a panel of MAbs directed against distinct protein epitopes of any complicated antigen containing carbohydrate with no necessity to purify it to a very high standard. In the current study, MAbs were obtained through the development of a new system of hybridoma screening which was based, on the one hand, on the use of $\mathrm{pPst}^{+}$ and pPst $^{-} \mathrm{Y}$. pestis strains constructed by genetic modification [9] for selection of MA bs specific for plaproducts encoded by pPst in IIFT, and on the other hand, on testing of MAbs for their ability to influence Fib functional activity (RFAI). This original system of 
Table 3. Comparison of specific properties of MAb-FI and MAb-Fib in IIFT

\begin{tabular}{lcccc}
\hline & $\begin{array}{c}\text { Number } \\
\text { of } \\
\text { Strains }\end{array}$ & $\begin{array}{c}\text { Cultivation } \\
\text { temperature } \\
\left({ }^{\circ} \mathrm{C}\right)\end{array}$ & \multicolumn{2}{c}{ Specific reaction with } \\
\cline { 4 - 5 } & 44 & 28 & MAb-FI & MAb-Fib \\
\hline Y. pestis & 44 & 37 & - & + \\
$\mathrm{pPst}^{+} ; \mathrm{pFra}^{+} ; \mathrm{pCad}^{+}$ & 8 & 28 & - & + \\
$\mathrm{pPst}^{+} ; \mathrm{pFra}^{+} ; \mathrm{pCad}^{-}$ & 8 & 37 & + & + \\
& 4 & 28 & - & + \\
$\mathrm{pPst}^{+} ; \mathrm{pFra}^{-} ; \mathrm{pCad}^{+}$ & 4 & 37 & - & + \\
& 6 & 28 & - & + \\
$\mathrm{pPst}^{+} ; \mathrm{pFra}^{-} ; \mathrm{pCad}^{-}$ & 6 & 37 & - & + \\
& 28 & 28 & - & - \\
$\mathrm{Y}^{-} \mathrm{pseudotuberculosis}$ & 28 & 37 & - & - \\
Y. enterocolitica & 13 & 28 & - & - \\
& 13 & 37 & - & - \\
\hline
\end{tabular}

screening appeared to be optimal and the data generated coincided with the combined results of the ELISA and IIFT. It should be mentioned that, in IIFT, Y. pestis cells cultivated at $28^{\circ} \mathrm{C}$ were used because, at $37^{\circ} \mathrm{C}$ but not at $28^{\circ} \mathrm{C}$, the organism forms a large capsule or envelope $[2,23]$ which covers other surface antigenic determinants of $Y$. pestis, including Fib [23]. The difference between the ELISA and IIFT data could be explained by: (i) decreased production of $\mathrm{Fib}$ when bacteria were grown at $28^{\circ} \mathrm{C}$; (ii) inaccessibility of $\mathrm{Fib}$ epitopes for MAbs because of cell wall LPS; (iii) heterogeneity of $\mathrm{Fib}$ preparation used for coating ELISA plates; (iv) as an enzyme, Fib can be inactivated easily under the influence of various factors. Modification of a native epitope of $Y$. pestis $F i b$ in the process of fixation with ethyl alcohol or on treatment with a detergent at different steps of the assays (dotELISA, ELISA, immunoblot, etc.) probably led to the loss of the antigen-antibody interaction.

ELISA and IIFT were the methods which allowed selection of MAbs to surface determinants of the microbial cell wall (both Fib and LPS). As the original Fib preparation contained a large amount of LPS, the selection of several hybridomas producing anti-LPS MAbs was expected and found; nine hybridomas positive in IIFT and ELISA were RFAI-negative (group $E)$. On the one hand, MAbs produced by group $E$ hybridomas could recognise an epitope responsible for the serological properties of Fib but not for its functional activity. On the other hand, they could be directed against $Y$. pestis cell-wall structures. Although Fib has been shown previously to be a pure protein [4$6]$, the difficulties of obtaining Fib preparations devoid of polysaccharide led to the supposition that this is a complex antigen-glycopeptide and that polysaccharide was a subunit of a complex Fib molecule [8]. Studies of the properties of MAb-E helped to solve this problem. This MAb possessed the following characteristics: (i) it was not able to inhibit fibrinolytic activity (i.e., was RFAI-negative); (ii) it reacted with both native and PK-digested Fib preparation; (iii) it reacted with Y. pestis LPS; (iv) it reacted with Y. pestis strains regardless of plasmid profiles, including strains devoid of plasmids, i.e., recognised determinants encoded by chromosomal genes; (v) it gave no reaction with other Enterobacteriaceae (Table 2). Interestingly, all MAbs produced by the group $E$ hybridomas demonstrated the same properties; as they were of $\operatorname{IgG}_{1}$ subclass they did not give non-specific cross-reactions. This suggests that the carbohydrate part of Fib was a Y. pestis cell-wall fragment, but not a subunit of a complex Fib molecule.

In contrast, 27 RFA I-positive M A bs A - C reacted only with native Fib preparations, but not with the PK digested antigen. This strongly indicated that the epitopes recognised had a protein nature.

Study of the spectrum of specific activities of MAbs $A-C$ in IIFT with $Y$. pestis containing different plasmids showed that only MAb-A detected all pPst ${ }^{+}$ $Y$. pestis strains. As for $M A b-B$ and $M A b-C$, they provided fewer positive reactions with the same strains (Table 2). As all pPst ${ }^{+}$strains used in the assay produced lysis of fibrin, this observation could be explained by different expression of epitopes which were recognised by both MAbs, B and C. Different expression of $\mathrm{Fib}$ epitopes could be connected with variable antigenic structure of $Y$. pestis strains from different natural foci [24]. The data obtained led to the conclusion that the epitopes recognised by these MAbs are encoded by pPst alone.

One of the most significant properties of the MAbs obtained was their ability to detect only $Y$. pestis strains. The pla protein was reported previously to share homology with other plasminogen activators [7]. Thus, sequencing of the pla gene revealed a high level of coincidence of its DNA sequence with one of gene E of S. typhimurium (69\%) and ompT of E. coli $(59 \%)$. This homology could be expected to predict similar properties of these gene products, including plasminogen activator activity. However, MAbs gave no crossreaction with other closely related bacteria, as well as the above-mentioned $S$. typhimurium and $E$. coli strains. It appears that $M A b s A-C$ recognised the 
species-specific epitopes of $Y$. pestis. These data agree with the fact that the pla gene does not possess complete homology with known plasminogen activators of bacterial (streptokinase and staphylokinase) or eukaryotic (urokinase and tissue plasminogen activator) origin [7]. The absence of homology between $Y$. pestis pla gene and genomes of a great number of gramnegative bacteria was confirmed by an examination of the relevant DNA sequences by the P1 probe, constructed on the basis of the site of the $Y$. pestis pla gene encoding Fib [6]. All these data strongly indicated a specific mechanism of $Y$. pestis fibrinolysis despite the number of observations [3-5] on the similar activity of other plasminogen activators.

The most striking property of MAbs A-C was their ability to detect $Y$. pestis strains cultivated at $37^{\circ} \mathrm{C}$ as well as at $28^{\circ} \mathrm{C}$, providing equally high levels of immunofluorescence in IIFT (Table 2). Cavanaugh and $M c D$ onough reported that the fibrinolytic activity is temperature-dependent, being higher at $37^{\circ} \mathrm{C}$ than at $28^{\circ} \mathrm{C}$ [5]. Thus, it could be expected that the specific activity of MAbs should follow the same pattern. However, MAbs appeared to be capable of detecting plague bacilli cultivated at $28^{\circ} \mathrm{C}$ with the same frequency as those cultivated at higher temperatures. This observation prompted the investigation as to whether MAbs reacted with both Fib and Coag; thus, RCAI was used to answer this question. All RFAIpositive MAbs appeared to inhibit the coagulase activity of $Y$. pestis. This was an indication that the MAbs recognised epitopes common to Fib and Coag. The results obtained were confirmed by immunoblotting analysis (Fig. 1). The bands visualised corresponded exactly to these two peptides of 37 and $35 \mathrm{kDa}$ previously identified as Y. pestis Fib and Coag $[4-6,8]$. The reaction of the MAbs with both Fib and Coag corroborated the immunochemical identity of two distinct subunits of a bifunctional peptide whose functional activity depends upon the temperature factor.

Existence of $\mathrm{Fib}$ and Coag in the form of a bifunctional protein is not a unique phenomenon. Several bacteria also have polyfunctional proteins composed of two and more distinct subunits involved in different biological reactions, e.g., anthranilate synthetase from Neurospora crassa [25], aspartokinase I-homoserine dehydrogenase I from E. coli [26], protein E of S. typhimurium [7]. Y. pestis itself has another polyfunctional peptide, 'murine' toxin, which demonstrates phospholipase D, kinase, phosphatase, phosphodiesterase, amylase and NAD-glycohydrolase activities $[27,28]$. A nother $Y$. pestis peptide possessing bifunctional activity is $\mathrm{V}$ antigen, whose dual role in virulence and in the regulation of the LCRS in Y. pestis has been shown by Skrzypek and Straley [29]. The probable explanation of the phenomenon of the existence of Fib and Coag in the form of a two-subunit bifunctional protein is through fusion of two independent genes in the process of evolution. As a result, the bacterium synthesises a so-called fusion peptide - one long protein chain instead of two. This is consistent with the experimental data of Truffa-Bachi et al. [30] which showed that two consequent frame-shift mutations on the sequence of two distinct genes of histidine biosynthesis of $S$. typhimurium caused translation of a single product. Further evidence of the Fib and Coag existence in the form of a bifunctional peptide is the impossibility of separating them by chromatographic methods $[6,8,23]$, including high-performance liquid chromatography [6]. In addition, both peptides, Fib and Coag, showed only one protein when subjected to continuous free-flow electrophoresis and PAGE without SDS [8].

It should be emphasised also that the MAbs obtained demonstrated the properties similar to those inherent in bi-specific MAbs produced by hybrid hybridomas. These MAbs (i) inhibited fibrinolytic activity of $Y$. pestis as well as coagulase, (ii) provided an equally high level of immunofluorescence in IIFT with Y. pestis cells cultivated at optimal conditions for synthesis of Fib $\left(37^{\circ} \mathrm{C}\right)$ and Coag $\left(28^{\circ} \mathrm{C}\right)$; and (iii) reacted with both 35- and $37-\mathrm{kDa}$ peptide bands in immunoblotting analysis. Thus, another fusion was not required to produce MA bs with bifunctional activity because of the properties of the $Y$. pestis Fib.

MAb-D lacked the ability to interact with $Y$. pestis strains in IIFT. This MAb was probably directed against an intracellular precursor of two pla forms (Fib and Coag) as described by Sodeinde and Goguen [4] and could not react with cell-surface structures.

The majority of $\mathrm{Y}$. pestis strains harbour three plasmids, pPst, pCad and pFra $[2,24]$. Two plasmids, pPst and pFra, have been detected only in Y. pestis [2]. So, the products encoded by these plasmids, especially $\mathrm{Fib}$ and $\mathrm{FI}$, being species-specific, serve as a basis for development of diagnostic preparations. However, Fib has advantages over $\mathrm{FI}$ (Table 3). Thus, MAb-Fib detected $Y$. pestis strains cultivated at $28^{\circ} \mathrm{C}$ as well as at $37^{\circ} \mathrm{C}$, whereas $\mathrm{MAb}-\mathrm{FI}$ reacted only with $\mathrm{Y}$. pestis strains cultivated at $37^{\circ} \mathrm{C}$. This phenomenon is possibly connected with the unique structure of $Y$. pestis Fib, immunochemically identical to $Y$. pestis coagulase. As coagulase activity of $Y$. pestis is observed at temperatures lower than $28^{\circ} \mathrm{C}[3,5,6]$, the M A b-Fib capable of recognising the relevant antigen can be used for the detection of $Y$. pestis strains in different specimens, especially in plague vectors. M oreover, there are some $Y$. pestis strains that lack $\mathrm{FI}$ antigen or produce it only at $37^{\circ} \mathrm{C}[2,14,23,24]$ and cannot be identified by the present serological methods. Furthermore, some data suggesting a non-specific character of several $\mathrm{FI}$ epitopes have been obtained [31, 32].

The use of MAb-Fib but not MAb-FI provided detection of $Y$. pestis $\mathrm{pPst}^{+}$strains which, being probably more virulent, are also the most dangerous 
epidemiologically, as strains that have lost pPst exhibit a marked increase in LD50 [2]. Although there are observations that $\mathrm{pPst}^{-}$mutants injected intravenously are fully virulent [2], there is no evidence for the absence of expression of antigens encoded by pPst in these $Y$. pestis strains. As this plasmid replicon is very likely capable of integration into the bacterial chromosome as well as pFra [33], expression of $\mathrm{Fib}$ in $\mathrm{pPst}^{-}$ strains can be explained by residence of the pla gene within the bacterial chromosome [7].

Being strictly specific, the MAb-Fib could be useful for differentiation between $Y$. pestis and $Y$. pseudotuberculosis - whose high level of genome homology has been shown previously [34]. Furthermore, Y. pseudotuberculosis was reported to form a capsule and it is unclear whether both Yersinia spp. have identical epitopes associated with the microbial capsule [31]. At the same time, Y. pseudotuberculosis exhibits neither fibrinolytic nor coagulase activity $[1,2,35]$. This marks Fib but not $\mathrm{FI}$ as the most diagnostically important $Y$. pestis antigen. It was easy to find plague bacilli in specimens of organs of mice after an acute challenge with virulent $Y$. pestis strain 231, by direct dot-ELISA. These data are corroborated by the data of $M C D$ onough et al [35], who used a fragment from pla region to specifically detect $Y$. pestis in fleas.

Titenko et al. [23] postulated that specific fluorescence of capsulate and non-capsulate plague bacilli stained with plague polyclonal luminescent immunoglobulins is provided by different antigens ( $\mathrm{FI}$ and Fib, respectively) emphasising that specific fluorescence of capsulate plague bacilli is due only to $\mathrm{FI}$. The MAb-Fib produced specific fluorescence of $Y$. pestis strains cultivated at both $37^{\circ} \mathrm{C}$ (capsulate) and at $28^{\circ} \mathrm{C}$ (non-capsulate) in IIFT. This means that surface Fib epitopes, being available for specific MAb, are not covered with $\mathrm{FI}$ antigenic determinants.

In summary, this study used a complicated screening assay procedure for testing specific and functional activities of MAbs. This approach provided an opportunity to select MAbs with different properties, the most important of which was inhibition of two distinct activities of $Y$. pestis. These MAbs recognised different epitopes of Fib which correlated with the reports of a polydeterminant structure for this antigen $[4,6,8]$. The use of the library of MAbs made it possible to get more precise information about the $Y$. pestis Fib antigenic molecule. A new technique was developed for reliable detection and serological identification of $Y$. pestis based on the use of strictly specific MAb-Fib. Further studies concerning the possible application of the MAbs obtained for improvement of the serological diagnosis of plague and extension of knowledge of the plague pathogen are in progress.

We thank Dr N. I. Lupikova for the gift of the Y. pestis fibrinolysin preparation, and Professor O. A. Protsenko for providing genetically modified Y. pestis strains. We are grateful to Mrs Ye. V. Mitina for excellent technical assistance and N. Ye. Teryoshkina for help in preparing the manuscript and continuous encouragement.

\section{References}

1. Madison RR. Fibrinolytic specificity of $B$. pestis. Proc SoC Exper Biol Med 1936; 34: 301-302.

2. Perry RD, Fetherston JD. Yersinia pestis - etiologic agent of plague. Clin Microbiol Rev 1997; 10: 35-66.

3. B eesley ED, B rubaker RR, Janssen WA, Surgalla MJ. Pesticins. III. Expression of coagulase and mechanism of fibrinolysis. J Bacteriol 1967; 94: 19-26.

4. Sodeinde OA, Goguen JD. Genetic analysis of the 9.5-kilobase virulence plasmid of Yersinia pestis. Infect Immun 1988; 56: 2743-2748

5. McDonough KA, Falkow S. A Yersinia pestis-specific DNA fragment encodes temperature-dependent coagulase and fibrinolysin-associated phenotypes. Mol Microbiol 1989; 3 767-775.

6. Bulgakova EG. Functional mapping of Yersinia pestis pPst. PhD thesis, Russia State Antiplague Research Institute 'M icrobe', Russia. 1991.

7. Sodeinde OA, Goguen JD. Nucleotide sequence of the plasminogen activator gene of Yersinia pestis: relationship to ompT of Escherichia coli and gene $E$ of Salmonella typhimurium. Infect Immun 1989; 57: 1517-1523.

8. Veinblat VI, Palagin AYu, K rongaus IV, Lopatkin ON. Isolation and physico-chemical characteristics of plague pathogen fibrinolysin preparations. Microbiol biochem Particularly dangerous infections. Russia, Saratov. 1988: 37-43.

9. Protsenko OA, Filippov AA, Kutyrev VV. [Plasmid heterogeneity in populations of Yersinia pestis strains.] Mol Gen Microbiol Virusol 1992; (3-4): 20-24.

10. Westphal 0 , Jann K. Bacterial lipopolysaccharides. Extraction with phenol-water and further applications of the procedure. In: Whistler RL, Bemillar JN, Wolfram ML (eds) Methods in carbohydrate chemistry, vol 5: General polysaccharides. New York, Academic Press, 1965: 83-91.

11. Galanos C, Luderitz O, Rietschel ET, Westphal O. A new method for the extraction of R lipopolysaccharides. Infect Rev Biochem 1977; 14: 239-235.

12. Galanos C, Lüderitz 0 , Westphal 0 . Preparation and properties of antisera against the lipid-A component of bacterial lipopolysaccharides. Eur J Biochem 1971; 24: 116-122.

13. Galfre G, Howe SC, Milstein C, Butcher GW, Howard JC. Antibodies to major histocompatibility antigens produced by hybrid cell lines. Nature 1977; 266: 550-552.

14. Devdariani ZL, Verenkov MS, Feodorova VA, Solodovnikov NS, Belov LG. Identification of Yersinia pestis with varied plasmid composition using monoclonal and polyclonal fluorescent immunoglobulins. FEM S Immunol Med Microbiol 1993; 6: 31- 35.

15. Ey $P L$, Prowse $S$ J, Jenkin $C R$. Isolation of pure $I g G_{1}, \lg G_{2}$ and $\mathrm{IgG}_{2 \mathrm{~b}}$ immunoglobulins from mouse serum using protein A-Sepharose. Immunochemistry 1978; 15: 429-436.

16. Ouchterlony 0 . Antigen-antibody reactions in gels. Types of reactions in coordinated systems of diffusion. Acta Pathol Microbiol Scand 1953; 32: 231-240.

17. Magnani JL, Brockhaus $M$, Smith DF et al. A monosialoganglioside is a monoclonal antibody-defined antigen of a colon carcinoma. Science 1981; 212: 55-56.

18. Hitchcock PJ, Brown TM. Morphological heterogeneity among Salmonella lipopolysaccharide chemotypes in silver-stained polyacrylamide gels. J Bacteriol 1983; 154: 269-277.

19. Nakane PK, Kawaoi A. Peroxidase-labeled antibody: a new method of conjugation. J Histochem Cytochem 1974; 22: 1084- 1091.

20. Naumov AV, Samoilova LV (eds) Manual on plague prophylaxis. Russia, Saratov. 1992: 217-221.

21. Laemmli UK. Cleavage of structural proteins during the assembly of the head of bacteriophage T4. Nature 1970; 227: $680-685$.

22. Towbin $\mathrm{H}$, Staehelin $\mathrm{T}, \mathrm{Gordon} J$. Electrophoretic transfer of proteins from polyacrylamide gels to nitrocellulose sheets: procedure and some applications. Proc Natl Acad Sci USA 1979; 76: 4350- 4354.

23. Titenko M M, Protsenko OA, Fursov VV et al. Informational 
value of the luminescent serologic method of $Y$. pestis diagnosis. Genetics and microbiology of natural focal infections. Russia, Saratov. 1984: 27-32.

24. Filippov AA, Solodovnikov NS, Kookleva LM, Protsenko OA. Plasmid content in Yersinia pestis strains of different origin. FEMS Microbiol Lett 1990; 67: 45- 48.

25. Hulett FM, DeMoss JA. Subunit structure of anthranilate synthetase from Neurospora crassa. J Biol Chem 1975; 250: 6648-6652.

26. Cowie DB, Truffa-Bachi $P$, Costrejean J-M, Py $M-C$, Cohen $G N$. A preliminary immunochemical study of $E$. coli aspartokinase I-homoserine dehydrogenase I. Biochem Biophys Res Commun 1973; 53: 188-193.

27. Kuzmichenko IA, Drozdovskaya FK. Phospholipase D activity of plague microbe. Problems of particularly dangerous infections. Russia, Saratov. 1977; 21-24.

28. Mishankin M B, A seyeva LE, Goncharov EK, Mishankin BN. Yersinia pestis 'murine' toxin: some enzyme activities. Bull Exp Biol Med 1995; 12: 602-605.

29. Skrzypek E, Straley SC. Differential effects of deletions in IcrV on secretion of $\mathrm{V}$ antigen regulation of the low- $\mathrm{Ca}^{2+}$ response, and virulence of Yersinia pestis. J Bacteriol 1995;
177: $2530-2542$.

30. Truffa-Bachi P, Cohen GN. A mino acid metabolism. Annu Rev Biochem 1973; 42: 113-134.

31. Gos̄nicka R, Gruszkiewicz E. Chemical composition and biological activity of the Yersinia pestis envelope substance. Infect Immun 1980; 30: 506-512.

32. Kosse LV, Lebedeva SA, Kuznetsova LS, Chernyavskaia AS, Zarenkov MI. [N ew data on the specificity and genetic control of the capsular antigen (FI) in Yersinia pestis.] Zhurn Microbiol Epidemiol Immunol 1997; 2: 29-33.

33. Protsenko OA, Filippov AA, Kutyrev VV. Integration of the plasmid encoding the synthesis of capsular antigen and murine toxin into Yersinia pestis chromosome. Microb Pathog 1991; 11: $123-128$.

34. Bercovier $\mathrm{H}$, Mollaret $\mathrm{HH}$, Alsonso JM et al. Intra- and interspecies relatedness of Yersinia pestis by DNA hybridization and its relationship to Yersinia pseudotuberculosis. Curr Microbiol 1980; 4: 225-229.

35. McDonough KA, Schwan TG, Thomas RE, Falkow $S$ Identification of a Yersinia pestis-specific DNA probe with potential for use in plague surveillance. J Clin Microbiol 1988 26: $2515-2519$ 